Article

\title{
Explaining Motivational Antecedents of Citizenship Behavior among Preservice Teachers
}

\section{Knut-Andreas Christophersen ${ }^{1}$, Eyvind Elstad ${ }^{2, *}$, Trond Solhaug ${ }^{3}$ and Are Turmo ${ }^{4}$}

1 Department of Political Science, University of Oslo, P.O. Box 1097, Blindern, 0317 Oslo, Norway; E-Mail: k.a.christophersen@stv.uio.no

2 Department of Teacher Education and School Research, University of Oslo, P.O. Box 1099 Blindern, 0317 Oslo, Norway

3 Programme for Teacher Education, Norwegian University of Science and Technology, 7491 Trondheim, Norway; E-Mail: trond.solhaug@plu.ntnu.no

4 The Norwegian Centre for Science Education, University of Oslo, P.O. Box 1106, Blindern, 0317 Oslo, Norway; E-Mail: are.turmo@naturfagsenteret.no

* Author to whom correspondence should be addressed; E-Mail: eyvind.elstad@ils.uio.no; Tel.: +47-9072-8604; Fax: +47-2285-4409.

Academic Editor: James Albright

Received: 11 February 2015 / Accepted: 15 April 2015 / Published: 23 April 2015

\begin{abstract}
A typical preservice teacher will experience demanding teaching situations during practicum. In such situations, interpersonal support from fellow students may be an important factor if experiences gained during teaching practice are to make a constructive contribution to personal growth for the teacher. Human support from other preservice teachers can bridge a gap that can be filled only to a limited extent by practice supervisors, who also have a role in assessing the students' practice periods. The phenomenon of preservice teachers helping their co-students - even though, strictly speaking, they have no formal responsibility in this area - is called citizenship behavior here. Structural equation modeling of questionnaire data collected among Norwegian preservice teachers shows that performance approach motivation is the factor most strongly associated with citizenship behavior. Intrinsic motivation is also a significant factor, both as a direct and an indirect effect, via study absorption. The self-efficacy of preservice teachers in teaching situations also has a robust association with citizenship behavior, while experiences involving pupil
\end{abstract}


engagement problems in teaching situations have a negative effect on self-efficacy. Pupil engagement problems also have an adverse impact on absorption.

Keywords: preservice teachers; teacher education; citizenship behavior; practicum; motivation; self-efficacy

\section{Introduction}

This article addresses the topic of preservice teachers helping one another in their development during teacher education. In recent decades, such helpfulness in workplaces has been termed organizational citizenship behavior (OCB). The concept is understood differently among organizations but is most often associated with supporting interpersonal behavior, team spirit, an element of innovation, and compliance with organizational needs [1]. Such behaviors seem particularly valuable in schools where many different tasks and challenges arise among pupils and teachers during the course of the year. Moreover, preservice teachers should be introduced to the concept in order to develop professionalism, in line with personal capacities, reasonable expectations, and the legal framework for teachers. Therefore, in this article, we argue that OCB among preservice teachers is important for their development as educators, particularly in preparation for future collaborative work in schools. Specifically, we explore factors related to teacher work and teaching experiences, which may influence helpful behavior among preservice teachers.

Why is helping behavior needed in teacher training? There may be two lines of arguments for OCB in teacher education: first, the need for supporting demands in teacher education and second, in preparation for OCB in future work situations in school.

As for the first line of argument, teaching situations in preservice teachers' practice can be affected by challenges in which they do not have a normal role as teachers on an equal footing with the school's regular teachers. Preservice teachers face numerous challenges in the complex work of teaching, on top of the fact that they are on trial [2]. They will therefore often lack the experience needed to master daily work like grading and often the potential authority that derives from regular teachers' power to determine academic grades and lead learning activities in class [3]. An integral characteristic of practice situations is preservice teachers' lack of experience and weaker authority than that of regular teachers [3]. This may often place preservice teachers in a particularly demanding position. For instance, it is not unusual for pupils to test the boundaries when a preservice teacher is teaching alone [3]. Teaching situations can therefore be experienced as particularly challenging, which may be reflected in the fact that preservice teachers spend far more time on tasks during teaching practice than is the case during campus-based teaching [4].

Preservice teachers will also be subject to assessment by practice supervisors and the educational institution's staff who attend the preservice teachers' teaching sessions [2]. For this reason, fellow students will often be an important source of support for preservice teachers, which is essential because these supportive activities provide teachers with additional resources [5].

More generally, a supportive climate may be essential to master and reflect upon teaching experiences and generally enhance students' wellbeing during their education. We summarize that 
supportive relationships with fellow students during teacher education are a vital element of their training and therefore constitute a quality feature of any teacher education program.

The second line of argument has two strands: First, collaboration among preservice teachers is often an explicitly designated behavior within the teacher education curriculum [6]. We regard OCB as somewhat integral to and a supplementary contribution to collaborative work.

Second, OCB in terms of helping colleagues, showing team spirit, support, and innovation, and contributing to collegial reflective practices as well as ensuring compliance, provides teacher collectives with a feeling of support and a positive spirit in schools. These behaviors also facilitate collaboration with students, colleagues, and parents, which is vital for teachers' in-role behavior [7,8].

An important challenge related to the organizational component in OCB is that preservice teachers will often have an unclear identity or sense of loyalty in relation to the teacher education institution. In the course of their teacher education, the vast majority of preservice teachers will have had experience of teaching practice in different schools (except for instance students who are following the Teach First program, whose teaching practice is held in the school where they are employed [9]). For this reason, preservice teachers may not experience a strong sense of identity or loyalty to one particular school [2,10]. On the other hand, they may experience close contact with fellow students, particularly during their teaching practice [11]. In Norway, usually two to four Norwegian preservice teachers (who have one or two academic subjects in common) have their practice as preservice teachers in at least two schools (generally covering different levels within the school system, such as primary and secondary). These practice periods are usually intense [12]. The question of loyalty (or duty/responsibility) should not be considered a relationship between the preservice teachers and the university or school, but a loyalty to other preservice teachers and/or colleagues in school practice. Support for fellow students is also reflected in our measurement items on OCB (see below).

Having argued that OCB is important to support preservice teachers and also important to teaching and school collectives we explore the motivational antecedents of citizenship behavior among preservice teachers. We argue that student motivation for various aspects of the teaching profession is of vital interest, particularly due to importance of knowledge of students' motivational contributions for teacher education. Consequently the concept of motivational orientation among preservice teachers is in this study understood in a broad sense; that is, several distinct motivational sub-dimensions, such as intrinsic motivation, achievement goal motivation, and altruistic motivation, are applied, as well as preservice teachers' self-efficacy for teaching. These concepts are explained below and our research aim is: We explore the statistical associations between preservice teachers' motivation, capabilities and challenging experiences on the one hand and OCB on the other. We apply a structural equation modeling approach, with 432 teacher education students in Norway as the study's participants.

\subsection{Review of Previous Research}

Research on OCB has produced some intriguing insights in a variety of organizational settings [13,14], but it has been neglected in the study on schools [15]. Searches in databases retune very few hits of which we would like to point out a study by Bogler and Somech in Israeli schools with interesting results in two articles [16,17]. They generally emphasize the importance of OCB in organizations [17]. For instance in his dissertation Darrel J. Cooper found a significant relationship between OCB and all 
measures of school effectiveness [18]. In the study by Bogler and Somech the authors focused on the relationship between teacher empowerment and teachers' organizational commitment, professional commitment (PC) and OCB among 983 teachers. In a quantitative survey they found that teacher decision-making, self-efficacy, and status were significant predictors of OCB [16]. Also, hierarchical regression analyses revealed that teacher empowerment played an important role in mediating the relationship between teachers' $\mathrm{PC}$ and OCB.

Involvement in decision-making processes induces teachers to take on new roles and have a more direct impact on school life, which in turn might lead them to invest extra effort in achieving school objectives. Principals and school administrators should acknowledge the importance of empowerment to teachers [17]. Vigoda-Gadot, Beeri, Birman-Shemesh, and Somech [19] studied the less conventional OCB at the group level among 206 teachers in 13 Israeli schools in order to develop new group level measures. Their findings corroborated previous OCB literature. The article ends with theoretical and practical implications for future studies that may focus on the "good platoon syndrome" of educational and other administrative systems rather than merely on the "good soldier syndrome". DiPaola and Hoy [20] completed an analysis of the characteristics of school organization that promote citizenship behaviors. They assumed that the leadership of the principal is critical and also the trust that colleagues have in each other and the extent to which there is a school press for academic achievement. Using a sample of 75 middle schools, their hypotheses were supported; all of these factors both individually and collectively have a positive influence on organizational citizenship. Very little research has been done on preservice teachers' OCB. DiPaola and Tschannen-Moran conducted two studies that confirmed the validity and reliability of new measures and found a strong relationship between OCB and the school climate [21]. Oplatka's study revealed that teachers who performed extra-role, non-obligatory, and unrewarded activities in teaching perceived these tasks as having some influence on themselves (e.g., a sense of self-fulfillment and higher levels of job satisfaction), their students (e.g., higher student achievements), and the whole school (e.g., improved school discipline and school image) [22]. Belogolovsky and Somech's research on teachers' OCB as in-role and extra-role behaviors based on a sampling of teachers, principals, and parents found incongruence among these three groups in what should be considered or expected as OCB [23]. This result implied that OCB might be contested in school. Inandi and Büyüközkan showed that OCB might influence teachers' wellbeing as a collective [24]. Burns and DiPaola indicated a positive relationship between teachers' OCB in high school and student achievement [15]. A significant relationship was found between student achievement on standardized tests and the OCB level of the faculty in the high school sample studied.

To summarize, OCB is here understood as partly in-role and partly extra-role behavior; the distinction is rather blurred. Research from several studies on OCB showed its positive relationship with school climate, teacher wellbeing, and student achievement, as well as other beneficial aspects of teaching and schooling - sufficient to claim OCB as an important aspect in educational institutions. However, the motivational antecedents of citizenship behavior are a neglected field of research.

\subsection{Theoretical Framework-Dependent Variable}

Organizational citizenship behavior, as the willingness to contribute to a larger collective, is a concept derived from political debates on citizens' role and citizenship, originating in the Greek 
polis $[25,26]$. While citizenship is most often national in scope, the term organization indicates a narrow framework (schools) for this larger collective. Today the political, liberal, strategic, and individualistic framework, which assumes that people act to pursue their own strategic interests, is seemingly growing. In the ultra-liberal view, citizenship is fairly individualized [27]. From such an ultra-liberal perspective, OCB is relevant as long as it is "in my strategic interest". Contrary to the ultra-liberals, republicans have always argued for participation to foster citizen awareness and willingness to contribute to a larger collective, which in this case is the school. We regard the OCB concept as situated in these larger debates over citizenship. The use of the term citizenship in OCB emphasizes the relationship between the individual teacher and the school community, pupils, colleagues, and leadership/authorities. The obvious normativity in OCB places it in a republican citizenship tradition. This is in line with an international, relative consensus that schools should foster citizens who are willing to make sacrifices or contribute to society [28]. Thus, OCB practices may be considered as modeling "citizenship" behavior in school.

All types of behavior in a teaching and learning context can be divided into two categories, first, the expected or in-role behavior and second, the type that is more difficult to define explicitly, for instance, in a teacher education curriculum [5,29]. The latter, often called extra-role behavior in behavioral science [30] - or more recently known as organizational citizenship behavior-has gradually become established as an important concept, denoting a sought-after characteristic of employees in many organizations, including schools [31-34]. Organ defined this phenomenon as "discretionary, not directly or explicitly recognized by the formal reward system, and that in the aggregate promotes the effective functioning of the organization" [13] (p. 4). Moon et al. reviewed the many conceptualizations of OCB (more than 30) and offered a model of two axes, a promotive versus a protective orientation and an interpersonal versus an organizational orientation [1]. Helpfulness, team spirit, innovation, and compliance are associated with varieties of OCB [1] (p. 6). However, these labels of behavior do not make it easy to determine what is in-role and what is extra-role behavior. Teaching inevitably involves relating to many different matters at the same time. Someone embarking on teacher education without prior teaching experience can easily be put off stride when too many tasks arise all at once [35]. The functional memory of preservice teachers, like that of other people, has a limited capacity to tackle unfamiliar situations. Experienced teachers have developed automatic routines that diminish the pressure on mental processing [36]. Both preservice teachers and their experienced colleagues may define the distinction between in-role and extra-role behavior differently. Thus, OCB may be considered partly extra-role and partly in-role behavior.

\subsection{Independent Variable and Hypothesis}

What factors can be proposed to explain citizenship behavior? First, all behavior is associated with some form of motivation, and preservice teachers may have different sorts of motivational leanings. Intrinsic motivation is a term used for motivation inspired by internal gratification [37]. Intrinsically motivated behavior is considered a volitional engagement in activities out of personal interest and spontaneous satisfaction [38]. Since personal satisfaction is related to intrinsic motivation [39], we argue that these students also find teaching rewarding and find fulfillment in helping and thus offer 
their contributions to education or in the course of their practice. Therefore, intrinsic motivation is expected to predict OCB (Hypothesis 1).

Another motivational category is performance approach motivation [40,41], originating from a need to be respected by others, regarded as a skilled person, and more generally, valued by society. By nature, citizenship behavior is positive and often highly valued by society for its contributions. This in turn may lead to favorable judgments and be rewarding for performance-motivated students. Thus, performance approach motivation is expected to predict citizenship behavior (Hypothesis 2). The justification for this hypothesis is that individuals can feel the need to be regarded as positive persons by those around them. A calculating element can thereby lie behind helping a fellow student.

It has been proposed that teachers and therefore, preservice teachers as well, have a genuine desire to work with other people, help pupils who need their assistance, etc. This can be called altruistic motivation for a future teaching career, which is identified as a distinct motivation among preservice teachers [42]. In other words, we believe that a personality characteristic of preservice teachers is their wish to be perceived as good role models through a future teaching career and that this will also generate altruism toward fellow students. Thus, altruistic motivation for a forthcoming teaching career is expected to predict citizenship behavior (Hypothesis 3). These three motivational categories are rooted in an individual's driving force, which can lead to action, whether the motivation for doing so is regarded as intrinsic, extrinsic, or altruistic.

In addition to motivation, personality type is a possible factor that can influence the degree to which a preservice teacher is inclined toward citizenship behavior. Study absorption is just such behavior that can be associated with a preservice teacher's extraordinary energy in situations during on-campus study periods and in circumstances that arise during teaching practice [43]. We propose that such energy is influenced by the educational balance between the challenges and the ability to handle them. If this balance is good, we will associate it with the phenomenon of flow [44]. Therefore, study absorption is expected to predict citizenship behavior (Hypothesis 4).

On the other hand, such issues as insurmountable discipline problems may be experienced as a negative factor for absorption (Hypothesis 5), since discipline problems can contribute to creating an imbalance between opportunities and challenges. It may also be argued that experiences of irregular behavior are most often associated with strain factors and may cause teacher burnout [8]. When students and teachers experience work pressures, they will have less energy for OCB. Consequently, we hypothesize that experiencing problem behavior may adversely affect OCB.

Second, behavior is associated with situations in which the preservice teacher exercises his or her profession. Self-efficacy denotes experiences of mastery during teaching practice, for instance. Bandura introduced the concept of self-efficacy beliefs as an assessment of a person's capabilities to attain a desired level of performance in a given endeavor [45]. Bandura assumes that belief in one's abilities is a powerful driving mechanism influencing the motivation to act, the effort put forth in the endeavor, and the persistence of coping mechanisms in the face of setbacks.

Bandura proposed four major influences on a preservice teacher's self-efficacy beliefs: mastery experiences, verbal persuasion, vicarious experiences, and physiological arousal [45]. The most powerful influence involves mastery experiences, which come from preservice teachers' actual instruction of pupils. Self-efficacy beliefs are enhanced if a preservice teacher perceives his or her teaching achievement to be a success, which then contributes to the expectations that future performances will 
likely be proficient. An increase in a preservice teacher's self-efficacy may result in greater effort, but failures lower self-efficacy beliefs, resulting in decreased motivation [46-48]. Arousal adds to a feeling of capability or incapability, depending on whether it is experienced as a sense of anxiety or excitement about an achievement. Research on preservice teachers' self-efficacy indicates that factors such as self-perceptions of instructional competence, personal characteristics [49], emotional and pedagogical support from fellow preservice teachers, as well as the teacher education program [50], contribute to teaching efficacy. Thus, teacher efficacy is expected to predict citizenship behavior (Hypothesis 6). However, causality may go in both directions between teacher efficacy and citizenship behavior. For preservice teachers, experiences gained in teaching during practice situations will be regarded as important factors that influence behavior. Preservice teachers may experience student engagement issues during their teaching practice, which will be demanding for them. Therefore, engagement problems may have an adverse effect on self-efficacy (Hypothesis 7).

\subsection{The Context}

Teacher education programs differ around the world [51]. In European programs, where Piaget and Vygotsky occupy a central role in the campus based program, preservice teachers are rarely presented with clear principles for action relating to a teacher's professional duties [52]. Philosophical reflection is a characteristic of Continental-European programs. However, attempts have been made to strengthen the contact between the teacher training institutions and schools in Europe by means of establishing institutional arrangements for partnerships [53]. In the United States, however, many programs contain courses that are much more oriented to introducing students to the pedagogical content knowledge of their discipline [54]. In the Asia-Pacific region the quality of the education workforce appears clearly tied to improving education outcomes, thus making preservice teachers become service professionals who put pressure on students with the aim of preparing a citizenry able to compete in the global economy [55]. In this landscape, the Norwegian teacher education programs have kinship with Continental-European programs [56].

In Norway, there are four frameworks for teacher education, two for the primary education years 1-5 and years 5-10 at university colleges, and two university programs for secondary level 8-13. One of these (the recent one established in 2005) is an integrated, five-year program. The old program includes an additional year (60 credit points) after completion of the regular university education.

In order to be accepted into the teacher education program of a Norwegian university, a preservice teacher should have completed adequate preliminary education (Master's degree in an academic subject/school-relevant subject and 60 credit points in another academic subject/school-relevant subject). The combination of adequate academic education and teacher training (called practical-pedagogic education or PPU in Norway) forms the qualification for teaching in Norwegian schools in years 8-13. This training is partly based on campus teaching and partly on a practicum in a school. A 60-day minimum of teaching practice is to be incorporated as an integrated part of the courses in pedagogy and subject-based didactics.

Teaching practice is a very important part of teacher education [2]. Even though students have studied academic subjects before teaching practice, some of them feel uncertain about their academic competence to teach in school. One reason for this is the varying degree of correspondence between the 
content of university academic courses and that of the school curriculum. For instance, the school subject of science consists of physics, biology, chemistry, and geology. Few students have taken all these subjects at university. The same is true of the school subject social studies, which draws on politics, social science, some sociology, some anthropology, and some economics. Students who will teach social studies will typically have an academic background in one or two of these subject areas. Even in cases where an academic discipline and a school subject do have corresponding titles (such as Norwegian), there will be clear differences in scope between the subject as studied at university and in school. For this reason, some students will experience insecurity in relation to their own academic capabilities. The teaching practice is supervised, assessed, and varied and can be carried out both individually and in groups. The time spent in individual teaching should normally be at least eight teaching hours per week and the teaching instruction should be related to subjects that the student is qualified to teach. For full-time students, the PPU consists of two, half-year terms (a year in total); the legally required 60 days of teaching practice are divided into two, with roughly half in each term. During the final term, students have longer teaching practice, which is assessed by means of a final practical examination (graded pass or fail). In collaboration with the field of practice, the individual institution establishes routines for quality assurance and practice assessment.

Students are often encouraged to work collaboratively, both in campus teaching and during practice in school. They may also practice together in groups, observing one another. Hence, both practice- and campus-based teaching present many challenges and opportunities, as well as topics for interpersonal contacts and OCB activities among students. This may be an important factor if experiences gained during teaching practice are to make a constructive contribution to personal growth in the role of the teacher.

Many preservice teachers have limited or no experience in the teaching profession before embarking on teaching practice. There will thus be potential uncertainty attached to students' belief in their own classroom management skills, in other words, their ability to maintain discipline and cope with the most aggressive children while attaining positive awareness from the pupils [8]. Particularly, students may encourage teacher efficacy in response to uncertainty regarding teaching academic content [45,57].

To summarize, the two cited teacher education curricular frameworks have clear statements of social competence, cooperation, care, and contribution to the school community, which may be interpreted as some kind of citizenship behavior expected in teacher practices. Consequently, it is of interest to the teacher education program how such citizenship behavior practices vary among students and what factors may contribute to such practices. The much appreciated, citizenship behavior practices during teacher education programs will likely be transferred and developed during actual professional teaching. However, an important question is whether any OCB practice is expected or may be characterized as extra-role behavior. One study [58] pointed out how crucial such behavior might be for any organization; OCBs - such as helping colleagues overloaded with work, coaching newcomers in the organization, or suggesting pedagogical or didactic improvements [23] are essential because these activities provide the school with additional resources $[5,13]$. 


\subsection{Empirical Survey Methodology}

\subsubsection{Arriving at the Model}

The reported analysis was part of a research project in which Norwegian preservice teachers' preferences were examined. A survey questionnaire was distributed to Norwegian preservice teachers in selected institutions (university colleges and universities). The questionnaire covered several topics and challenges related to teacher education. We explored several variables, including gender and type of institution (university colleges versus universities), to arrive at the best possible model. In the exploration, no other variable, that we considered theoretically meaningful, proved to have significant relationships with OCB. The presented model is therefore the best possible empirical and theoretically meaningful model in our dataset.

\subsubsection{Selection of Students}

The survey required the following inclusion criteria for the groups of preservice teachers:

1. one-year, undergraduate teacher education program for candidates with a vocational or general academic background;

2. integrated five-year, senior teacher education program at a university;

3. primary teacher education program (for teaching in grades 1-7);

4. primary/secondary teacher education program (for teaching in grades 5-10); and

5. general teacher education program (for teaching in grades 1-10), i.e., the old model.

The survey was carried out during the spring and autumn of 2013. The data was collected by using two methods. (1) Students following the senior-teacher program and the teacher education program at a university, as well as primary/secondary/general preservice teachers at a university college, were given the paper-based questionnaire during the obligatory seminar teaching. The students were informed that participation was voluntary and that they could withdraw from the survey at any point. The response rate was $100 \%$. Data were processed with assistance from the information and communication technology (ICT) support staff at the Norwegian University of Science and Technology; (2) The other part of the sampling procedure was based on a snowball strategy for sampling. Students at four Norwegian university colleges with primary/secondary/general teacher programs took part in an electronic questionnaire administered by the firm Advicia. The teacher education institutions gave the preservice teachers' email addresses to the researchers, who sent the electronic questionnaire to these email addresses. It was not possible to estimate the exact response rate in this sample because a number of students were not users of the allocated e-mail addresses at two institutions. Nonetheless, a comparison of gender and age showed that this sample represented the characteristics of the general population of preservice teachers at the university colleges. Further validation was done via comparison of time-on-task measures in our investigation and a similar one undertaken by the Norwegian Agency for Quality Assurance in Education (NOKUT) in the previously mentioned survey. The average measures were quite similar. These validation efforts indicated that some characteristics of our sample from the electronic questionnaire were similar to those of the reference population among Norwegian preservice teachers. 
Work engagement was assessed using the Utrecht Work Engagement Scale (UWES) [43]. Absorption is characterized as being fully concentrated and happily engrossed in one's work, whereby time passes quickly and one has difficulty in detaching oneself from work. The UWES consists of 17 items measuring three subscales that reflect the underlying dimensions of engagement. We selected one of these scales.

\subsubsection{Measurement Instruments}

A questionnaire was constructed, based on measurement instruments previously reported in the literature, as well as new developments. The preservice teachers responded to the survey items on a seven-point Likert scale, where the alternative "four" represented a neutral midpoint. The concepts were measured with two to three single items. The analysis reported in the next section is based on seven measurement instruments. The internal consistency for each concept is satisfactory, with Cronbach's alpha between 0.71 and 0.89 (see Table 1).

Table 1. Overview of constructs and items.

\section{Concepts and Indicators}

Cronbach's Alpha

Intrinsic motivation, IM [59]

I want to be a teacher because:

I want others to be interested in learning;

working with children and young people is meaningful.

Performance approach motivation, PM [60]

It is important to me:

to be looked up to by the other students;

0.78

to be described as the best in the study group.

Altruistic motivation, FG [42]

It is important to me:

to work with people;

to help people who need it.

Perceived discipline problems during teaching practice, PB [61]

Pupils disturbing their fellow pupils in their work:

pupils breaking class rules;

pupils making unnecessary noise;

pupils leaving their desks without asking permission.

Study absorption, AB [43]

I am so captivated by my studies that I almost forget the things around me.

I find it difficult to tear myself away when I get going with reading study texts.

I feel full of energy when I am working on my studies.

Self-efficacy in student engagement, EN [8]

To what extent will you as a future teacher:

manage to motivate those pupils who show little interest in school work?

manage to get the pupils to believe that they can actually do well in school?

manage to get the pupils to be ambitious?

Citizenship behavior among preservice teachers (OC)

I freely help other preservice teachers with teaching-related questions.

I help other preservice teachers even though it is not strictly my responsibility. 
In our questionnaire all concepts are measured with 3-4 items. However, in our preparations of the construct variables - using confirmatory factor analysis (CFA) - some items fit only moderately to the data matrix. These situations raise dilemmas over concept validity versus statistical model fit. Generally we have given moderate priority to model fit in data which also reflect most clearly what the data matrix reveals in terms of findings. This priority also explains why we only have two items in our dependent variable. However, we argue that our items reflect the core of OCB which is theoretically underlined and focused as the aim of our analysis.

\subsubsection{Analysis}

Structural equation modeling (SEM) was used to analyze the relationships among the variables. The SEM is suitable for confirmatory factor analysis and path analysis. Assessments of fit between model and data are based on the following indices: root mean square error of approximation (RMSEA), normed fit index (NFI), goodness-of-fit index (GFI), and comparative fit index (CFI). The RMSEA $<0.05$ and NFI, GFI, and CFI $>0.95$ indicate good fit, while RMSEA $<0.08$ and NFI, GFI, and CFI $>0.90$ indicate acceptable fit [62]. The measurement and structural models were estimated with IBM SPSS Amos 21. The values of RMSEA, NFI, GFI, and CFI indicate that the structural model in Figure 1 has good fit.

\section{SEM analysis with Citizenship behavior as dependent variable, $N=432$}

Path coefficients $\rightarrow$ : Standardized estimates

Correlation coefficients <..>: Pearsons $r$

Numbers in Italic: Significant coefficients at the 5\%-level

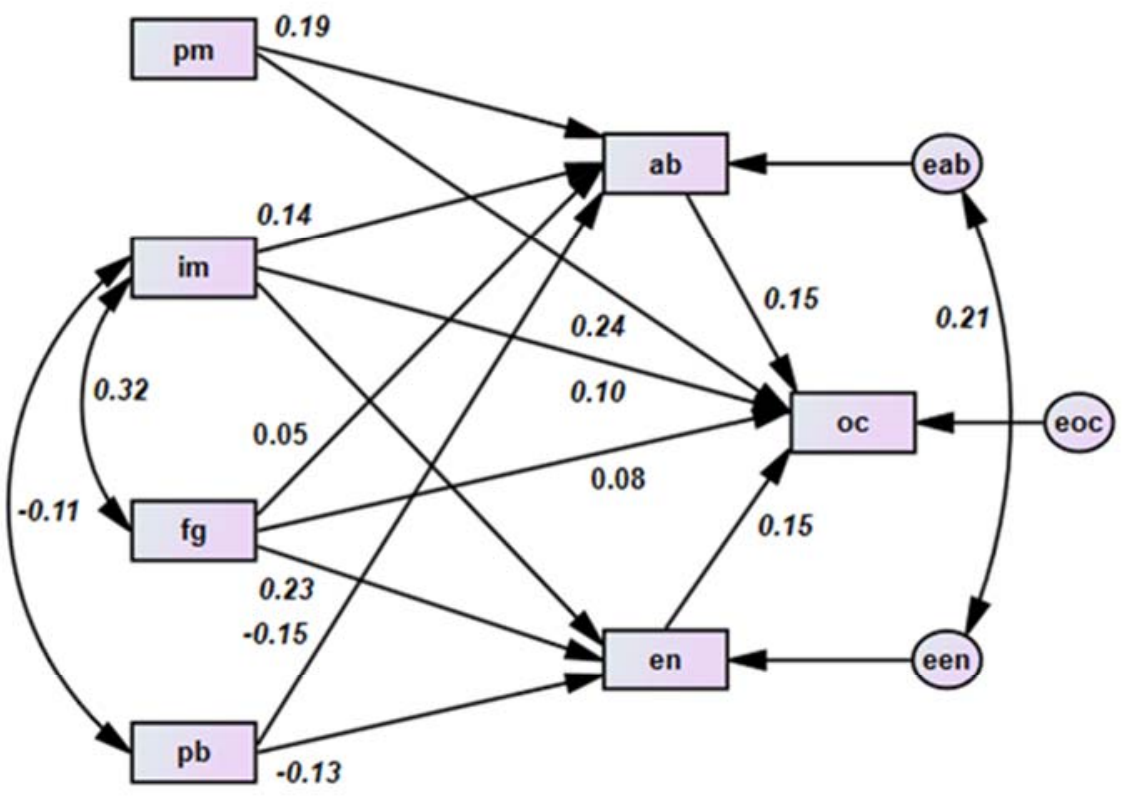

Iformat

p-chi $=0.394$ rmsea $=0.010$ nfi $=0.980$ cfi $=0.999$ gfi $=0.996$

R-square $(\mathrm{ab})=0.09, \mathrm{R}$-square $(\mathrm{en})=0.22$ og R-square $(\mathrm{oc})=0.18$

Dependent variable: oc $\rightarrow$ Citizenship behavior

Mediating variables: $a b \rightarrow$ Study absorption $\&$ en $\rightarrow$ Self-efficacy in student engagement

Preceding variables: $\mathrm{pm} \rightarrow$ Achievement goal motivation; im $\rightarrow$ Intrinsic motivation

$; f g \rightarrow$ Altruistic motivation; \& pb $\rightarrow$ Perceived discipline problems during teaching practice

Figure 1. Antecedents of citizenship behavior among preservice teachers $(N=432)$. 


\section{Empirical Results}

Figure 1 presents the estimated structural model. Table 2 provides an overview of the results related to the hypotheses.

Table 2. Overview of results related to the hypotheses.

\begin{tabular}{crc}
\hline Hypothesis & Statement & Result \\
\hline Hypothesis 1 & Intrinsic motivation predicts citizenship behavior. & Rejected \\
Hypothesis 2 & Achievement goal motivation predicts citizenship behavior. & Supported \\
Hypothesis 3 & Altruistic motivation predicts citizenship behavior. & Rejected \\
Hypothesis 4 & Study absorption predicts citizenship behavior. & Rejected \\
Hypothesis 5 & Discipline problems are negatively associated with absorption. & Weakly supported \\
Hypothesis 6 & Self-efficacy predicts citizenship behavior. & Weakly supported \\
Hypothesis 7 & Engagement problems are negatively associated with self-efficacy. & Rejected \\
\hline
\end{tabular}

The analysis indicates that achievement goal motivation (PM, $\beta=0.24)$ is the factor most strongly associated with citizenship behavior. There is also an indirect effect $(\beta=0.19)$ via study absorption. This statistical connection does not need to be a causal relationship $\beta$, but may also be understood as a consequence of a common but unidentified, causal factor. We require an entire battery of personality categories in empirical research to gain a better understanding of what aspects of a preservice teacher's personality can contribute to the development of citizenship behavior during teaching practice. A key question is thus what factors contribute to performance approach motivation in teacher education. One possible interpretation is that these findings put us on the right track toward an understanding of how others perceive one's performance, which may be significant for the degree of citizenship behavior that is exhibited. People's desire to project a positive impression of themselves to others can motivate them to show citizenship behavior. If this interpretation does reflect genuine causal processes, the challenge may be to ensure that situations arise in which performance approach motivation can be developed during teaching practice.

As the analysis shows, intrinsic motivation (IM, $\beta=0.10$ ) is also significant in this respect, both as a direct and an indirect effect through study absorption $(\beta=0.14)$. Intrinsic motivation reflects the pleasure and positive experiences of participating in a teaching role in the practice schools. Of course, this is a positive mechanism in every sense of the word, both for the teacher education and for the individual preservice teacher. We find that absorption is also a significant factor for citizenship behavior, together with both intrinsic motivation and performance approach motivation.

Absorption is related to citizenship behavior (OC) $(\beta=0.15)$. The variable may be understood as a consequence of finding oneself in the correct niche in life and can be regarded as a kind of flow condition. On the other hand, we observe that absorption is negatively affected by student engagement problems in the school $(\mathrm{EN})(\beta=-0.15)$. In other words, a teacher education program should avoid school classes that have excessive engagement problems if it intends to lay the groundwork for citizenship behavior during teaching practice. Preservice teachers' ability to engage pupils is significantly but also moderately associated with $\mathrm{OC}(\beta=0.15)$. The analysis shows that preservice teachers' self-efficacy in teaching situations has a clear statistical association with citizenship 
behavior. Additionally, encountering discipline problems in teaching situations has a negative impact on self-efficacy.

Surprisingly, the hypothesis regarding altruistic motivation for a future teaching career does not gain support $(\beta=0.08)$. We believed that preservice teachers with a desire to act as positive role models for future pupils would also display altruistic motives in their behavior during teacher education. The weak empirical correlation in this respect evidently calls for in-depth research to gain a better understanding of the relationship between altruistic motivation and citizenship behavior.

\section{Discussion}

Our results support the hypothesis that performance approach motivation predicts citizenship behavior among preservice teachers. The mechanism behind this finding is likely to be the fact that performance approach motivation originates from a need to be respected by others, regarded as a skilled person and valued by society. This may lead to favorable judgments and be rewarding to performance-motivated students. The preservice teachers may feel a significant need to be regarded as a positive person. A calculating element can thereby lie behind helping a fellow student. We can confidently state that motivation precedes action, but it can also be argued that causality may operate in other directions than assumed in our hypothetical model. More research along the same lines will help our understanding of the assumed causal relationships and of the mechanisms that we assume to be responsible for what we are measuring.

Discipline problems may contribute to creating an imbalance between opportunities and challenges. Experiences of irregular behavior are most often associated with strain factors and may cause teacher burnout. Discipline problems may thus be experienced as a negative factor for preservice teachers' absorption, which is also supported by our analysis.

Self-efficacy beliefs are enhanced if a preservice teacher perceives his or her teaching achievement as a success, which then contributes to the expectations that future performances will likely be proficient. An increase in self-efficacy may result in greater effort. Previous research on preservice teachers' self-efficacy indicates that factors such as self-perceptions of instructional competence and personal characteristics contribute to teaching efficacy. We interpret our finding of teacher efficacy generating citizenship behavior using this perspective, however the potential causality may go in both directions.

So far, we have focused on the motivational variables that are closely associated with personality aspects. However, the actual situations in which preservice teachers operate are also significant in terms of citizenship behavior. As mentioned above, student engagement problems have a negative effect on study absorption. We must conclude here that excessive engagement problems among students will have an unfavorable impact on preservice teachers' feeling of mastery and experience of positive dynamics during the practice period. This is an important finding. Out of consideration for the research method's emphasis on parsimonious modeling, we have had to limit the battery of tests in several aspects of preservice teachers' self-efficacy. We deem it important to extend the scope of this dimension in future empirical research by introducing additional conceptual distinctions within self-efficacy, which can reflect the multifaceted nature of mastery in teaching practice. 


\subsection{Limitations of Study}

Among the several limitations in this study, this type of analysis has drawbacks from a conceptual perspective (parsimonious modeling) and its methodological (cross-sectional) approach. We acknowledge these limitations and argue that they can serve as points of departure for future research. The study's heavy reliance on self-reported questionnaire data puts the results into question and makes the subjective component undeniable. Independent judgments can provide interesting data about each preservice teacher's performance, but it is difficult to carry out this process while honoring the promise of anonymity.

As in other studies, there are also insufficient controls in this research. However, controlled experiments are normally beyond the realm of possibility for educational researchers. At any rate, studying development processes in some schools, which in many respects have substantial similarities apart from the one aspect being studied, can set us on the trail of causal processes.

Multiple factors may influence behavior. Longitudinal and quasi-experimental studies are needed to determine causality. Cross-sectional studies only represent a momentary observation of an organization and do not allow for the testing of causal relationships among antecedents. Reversed causation may play a role. Omitted variables might have influenced the overall model, and these missing variables could be important. Further longitudinal research is needed to address the complexity of the interactional dynamics between leaders and teachers and the associated impacts on teacher motivation.

Another deficiency is the limited number of concepts and antecedents examined in this study. Factors outside the school system could also influence preservice teachers' citizenship behavior and should have been included.

A final limitation is the sample of preservice teachers. The exact response rate of the e-mail survey is difficult to determine due to some inactive e-mail addresses. The moderate (compared to those of corresponding studies) response rates leave uncertainty about whether the samples are representative of the whole population of preservice teachers in Norway. However, response rates within this range are not unusual in social science studies. In sum, these shortcomings provide direction for future research.

\subsection{Implications for Practice and Further Studies}

We argue that citizenship behavior is an under-regarded dimension of good teacher education. Teacher educators may stimulate helpfulness among preservice teachers by deliberately gathering small groups of students who initially have good relations or modeling citizenship behavior during practice periods. Despite its limitations, this study contributes to the knowledge of the factors influencing preservice teachers' citizenship behavior. If the associations among the independent, mediating, and dependent variables represent causal relationships, our findings may have implications for practice. In Norway, as in many other European countries, there is substantial transfer from teacher education to other career pursuits [63]; at the same time, a significant shortfall of teachers is predicted within a few years [64]. Measures that will help reduce dropouts during the course of teacher education are therefore welcome as a contribution to securing the future supply of teachers needed by the schools. Enabling citizenship behavior to flourish among preservice teachers may be one of several possible tactics. 
In the context of today's teacher education, OCB is mainly regarded as extra-role behavior. It is natural that citizenship behavior is considered a civic virtue, similar to altruism or conscientiousness [13]. These characteristics demand authentic behavior if preservice teachers are to discover their true potential. From such a perspective, it can be paradoxical to define citizenship behavior as part of the formal teacher education curriculum (in other words, as in-role behavior). Rewarding citizenship behavior, for instance, by enhancing grades in teaching practice, can be construed as turning an emotional-ethical value into a utilitarian one. On the other hand, it is possible to pave the way for genuine helpfulness among preservice teachers by deliberately gathering small groups of students who have good "personal chemistry" or modeling OCB relationships during practice periods. A stronger implication is to train them in preparation for citizenship behavior.

Moreover, school classes that have substantial pupil engagement problems are unhelpful in terms of promoting citizenship behavior, as already noted. On the other hand, engagement problems are an ever-present issue in Norwegian schools. Despite surveys indicating the somewhat reduced extent of engagement problems [65], Norwegian schools still offer considerable challenges to teachers' engagement management. One function of teacher education is to prepare an individual for working life, so if the incidence of realistic challenges encountered during education is reduced, it prepares preservice teachers for a deceptively easy teaching environment. Practicum could begin with a sheltered introduction to teaching practice [66]. Nevertheless, preservice teachers and newly qualified teachers will find it easier to grow into their role as leaders of learning processes if there is a reasonable balance between challenges and opportunities. In our opinion, this latter consideration should weigh heavily in the choice of school classes for preservice teachers' teaching practice.

\section{Conclusions}

The conclusion of our analysis is that performance approach motivation is the factor most strongly associated with citizenship behavior among preservice teachers. Intrinsic motivation is also a significant factor, both as a direct and an indirect effect, via study absorption. Self-efficacy in teaching situations is associated with citizenship behavior. Experiences involving pupil engagement problems in teaching situations have a negative effect on self-efficacy. Pupil engagement problems also have an adverse impact on preservice teachers' absorption.

Substantial research is available regarding collaboration among preservice teachers during teaching practice and otherwise during teacher education. This refers to activities designed by the teacher education institution. What we have dealt with in this article is often the kind of spontaneous and informal helpfulness which, we have argued, fills a potential gap in the provisions designed to support the preservice teachers' personal growth in their performance of the teaching role. Furthermore, engaged preservice teachers show beneficial behaviors toward their colleagues. To our best knowledge, this issue has not been specifically addressed in prior research. For this reason, we believe that teacher education institutions should take account of this factor in their plans to provide solid education for teachers. In this article, we have attempted to identify factors statistically associated with citizenship behavior. We conclude that both intrinsic and performance approach motivation appear to be antecedents of citizenship behavior. Self-efficacy also seems to play a significant role. This may put us on the right path of what researchers should be seeking to gain better insights into factors of 
significance for high-quality teacher education. In our own future research, we will therefore attempt to follow up on the findings described here by deploying a broader set of theoretical variables, which will form a basis on which to deduce testable, empirical traces of factors that can explain citizenship behavior. It is also our hope that other researchers may take an interest in this issue which, in our opinion, is an important marker of quality in a successful teacher education program.

\section{Acknowledgments}

We thank Kyrre Svarva at Norwegian University of Science and Technology, Faculty of Social Science and Technology Management IT-support section for providing an excellent questionnaire and for scanning parts of the selected student responses.

\section{Author Contributions}

The four authors contributed equally to this work.

\section{Conflicts of Interest}

The authors declare no conflict of interest.

\section{References}

1. Moon, H.; van Dine, L.; Wrobel, K. The circumplex model and the future of organizational citizenship behavior research. In Handbook of Organizational Citizenship Behavior. A Review of Good Soldier Activity in Organizations; Turnipssed, D.L., Ed.; Nova Science Publishers: New York, NY, USA, 2005.

2. Darling-Hammond, L.; Lieberman, A. Teacher Education around the World: Changing Policies and Practices; Routledge: New York, NY, USA, 2012.

3. Calderhead, J. The nature and growth of knowledge in student teaching. Teach. Teach. Educ. 2002, 7, 531-536.

4. Martinussen, G.; Smestad, B. Allmennlærerstudenters arbeidsinnsats: Bedre enn sitt rykte? In FoU i Praksis 2010. Rapport fra Konferanse om Praksisrettet FoU i Lœrerutdanning; Hoel, T.L., Guldal, T.M., Dons, C.F., Sagberg, S., Solhaug, T., Wæge, K., Eds.; Tapir: Trondheim, Norway, 2011; pp. 331-340. (In Norwegian)

5. Christ, O.; van Dick, R.; Wagner, U.; Stellmacher, J. When teachers go the extra mile: Foci of organisational identification as determinants of different forms of organisational citizenship behaviour among schoolteachers. Br. J. Educ. Psychol. 2003, 73, 329-341.

6. Ministry of Education. Rammeplan for Praktisk-Pedagogisk Utdanning; Ministry of Education: Oslo, Norway, 2003.

7. Darling-Hammond, L. Assessing teacher education-The usefulness of multiple measures for assessing program outcomes. J. Teach. Educ. 2006, 57, 120-138.

8. Skaalvik, E.M.; Skaalvik, S. Dimensions of teacher self-efficacy and relations with strain factors, perceived collective teacher efficacy, and teacher burnout. J. Educ. Psychol. 2007, 99, 611-625. 
9. Nesje, K. Teach First Norway. Nye modeller i lærerutdanningen. In Profesjonsutvikling i Skolen; Elstad, E., Helstad, K., Eds.; Universitetsforlaget: Oslo, Norway, 2014. (In Norwegian)

10. Cohen (Sayag), E.; Hoz, R.; Kaplan, H. The practicum in pre-service teacher education: A review of empirical studies. Teach. Educ. 2013, 24, 345-380.

11. Zeichner, K. Rethinking the connections between campus courses and field experiences in college- and university-based teacher education. J. Teach. Educ. 2010, 61, 89-99.

12. Calderhead, J., Ed. The development of knowledge structures in learning to teach. In Teachers' Professional Learning; Falmer Press: London, UK, 1988.

13. Organ, D.W. Organizational Citizenship Behavior: The Good Soldier Syndrome; Lexington Books: Lexington, MA, USA, 1988.

14. Organ, D.W.; Ryan, K. A meta-analytic review of attitudinal and dispositional predictors of organizational citizenship behavior. Pers. Psychol. 1995, 48, 775-802.

15. Burns, W.R.T.; di Paola, M.F. A study of organizational justice, organizational citizenship behavior, and student achievement in high schools. Am. Second. Educ. 2013, 42, 4-23.

16. Bogler, R.; Somech, A. Influence of Teacher Empowerment on Teachers' Organizational Commitment, Professional Commitment and Organizational Citizenship Behavior in Schools. Teach. Teach. Educ. 2004, 20, 277-289.

17. Bogler, R.; Somech, A. Organizational Citizenship Behavior in School: How Does It Relate to Participation in Decision Making? J. Educ. Adm. 2005, 43, 420-438.

18. Cooper, J. Darrell: Collective Efficacy, Organizational Citizenship Behavior, and School Effectiveness in Alabama Public High Schools. Ph.D. Dissertation, The University of Alabama, Tuscaloosa, 2010. Available online: http://acumen.lib.ua.edu/content/u0015/ 0000001/0000417/u0015_0000001_0000417.pdf (accessed on 18 April 2015).

19. Vigoda-Gadot, E.; Beeri, I.; Birman-Shemesh, T.; Somech, A. Group-Level Organizational Citizenship Behavior in the Education System: A Scale Reconstruction and Validation. Educ. Adm. Q. 2007, 43, 462-493.

20. Di Paola, M.F.; Hoy, W.K. School Characteristics that Foster Organizational Citizenship Behavior Source. J. Sch. Leadersh. 2005, 15, 387-406.

21. DiPaola, M.; Tschannen-Moran, M. Organizational citizenship behavior in schools and its relationship to school climate. J. Sch. Leadersh. 2001, 11, 424-447.

22. Oplatka, I. Organizational citizenship behavior in teaching: The consequences for teachers, pupils, and the school. Int. J. Educ. Manag. 2009, 23, 375-389.

23. Belogolovsky, E.; Somech, A. Teachers' organizational citizenship behavior: Examining the boundary between in-role behavior and extra-role behavior from the perspective of teachers, principals and parents. Teach. Teach. Educ. 2010, 26, 914-923.

24. Inandi, Y.; Büyüközkan, A.S. The effect of organizational citizenship behaviours of primary school teachers on their burnout. Educ. Sci. 2013, 13, 1545-1550.

25. Mansbridge, J. On the idea that participation makes better citizens. In Citizen Competence and Democratic Institutions; Elkin, S.L., Soltan, K.E., Eds.; The Pennsylvania State University Press: University Park, PA, USA, 1999; pp. 291-311.

26. Ball, S.J. The Education Debate; Policy Press: Bristol, UK, 2013. 
27. Schuck, P.H. Liberal Citizenship. In Handbook of Citizenship Studies; Isin, E.F., Turner, B.S., Eds.; Sage: London, UK, 2002; pp. 131-144.

28. Hughes, A.; Print, M.; Sears, A. Curriculum capacity and citizenship education: A comparative analysis. Compare 2010, 40, 293-309.

29. Somech, A.; Drach-Zahavy, A. Understanding extra-role behavior in schools: The relationships between job satisfaction, sense of efficacy, and teachers' extra-role behaviour. Teach. Teach. Educ. 2000, 16, 649-659.

30. Katz, D. The motivational basis of organizational behavior. Behav. Sci. 1964, 9, 131-133.

31. Turnipseed, D.L. Handbook of Organizational Citizenship Behavior. A Review of Good Soldier Activity in Organizations; Turnipseed, D.L., Ed.; Nova Science Publishers: New York, NY, USA, 2005.

32. Elstad, E.; Christophersen, K.A.; Turmo, A. Social Exchange Theory as Explanation of Teacher Organizational Citizenship Behavior. Int. J. Leadersh. Educ. 2011, 14, 405-422.

33. Elstad, E.; Christophersen, K.A.; Turmo, A. Exploring antecedents of organizational citizenship behaviour among teachers at Norwegian folk high schools. Stud. Contin. Educ. 2012, 34, 175-190.

34. Elstad, E.; Christophersen, K.A.; Turmo, A. Antecedents of Organizational Citizenship Behavior among Educators in Language Education for Adult Immigrants in Norway. Adult Educ. Q. 2013, 63, 78-96.

35. Leinhardt, G.; Greeno, J.G. The cognitive skill of teaching. J. Educ. Psychol. 1986, 78, 75-95.

36. Kounin, J. Discipline and Group Management in Classrooms; Holt, Rinehardt and Winston: New York, NY, USA, 1977.

37. Ryan, R.M.; Deci, E.L. Intrinsic and extrinsic motivations: Classic definitions and new directions. Contemp. Educ. Psychol. 2000, 25, 54-67.

38. Ryan, R.M.; Deci, E.L. On assimilatiing identities to the self: A self-determination theory perspective on internalization and integrity within cultures. In Handbook of Self and Identity; Leary, I.M.R., Tangney, J.P., Eds.; Guilford Press: New York, NY, USA, 2003; pp. 253-275.

39. Joan, D.; Wilson, S.M. Principals' efforts to empower teachers: Effects on teacher motivation and job satisfaction and stress. Clear. House 2000, 73, 349-353.

40. Pintrich, P.R. An achievement goal theory perspective on issues in motivation terminology, theory, and research. Contemp. Educ. Psychol. 2000, 25, 92-104.

41. Malmberg, L.E. Goal-orientation and teacher motivation among teacher applicants and preservice teachers. Teach. Teach. Educ. 2006, 22, 58-76.

42. Roness, D. Still motivated? The motivation for teaching during the second year in the profession. Teach. Teach. Educ. 2011, 27, 628-638.

43. Schaufeli, W.B.; Bakker, A.B.; Salanova, M. The measurement of work engagement with a short questionnaire. A cross-national study. Educ. Psychol. Meas. 2006, 66, 701-716.

44. Csikszentmihalyi, M. Flow: The Psychology of Optimal Experience; Harper and Row: New York, NY, USA, 2000.

45. Bandura, A. Self-Efficacy, the Exercise of Control; W.H. Freeman and Company: New York, NY, USA, 1997.

46. Guskey, T.R. Measurement of responsibility teachers assume for academic successes and failures in the classroom. J. Teach. Educ. 1981, 32, 44-51. 
47. Ross, J.A. Antecedents and consequences of teacher efficacy. In Advances in Research on Teaching; Brophy, J., Ed.; JAI Press: Greenwich, CT, USA, 1998; Volume 7, pp. 49-74.

48. Tschannen-Moran, M.; Woolfolk-Hoy, A.; Hoy, W.K. Teacher efficacy: Its meaning and measure. Rev. Educ. Res. 1998, 68, 202-248.

49. Poulou, M. Personal teaching efficacy and its sources: Preservice teachers' perceptions. Educ. Psychol. 2007, 27, 191-218.

50. Tschannen-Moran, M.; Hoy, A.; Woolfolk, A.E. The differential antecedents of self-efficacy beliefs of novice and experienced teachers. Teach. Teach. Educ. 2007, 23, 944-956.

51. Darling-Hammond, L. Constructing 21st-century teacher education. J. Teach. Educ. 2006, 57, 300-314.

52. Blömeke, S.; Paine, L. Getting the fish out of the water: Considering benefits and problems of doing research on teacher education at an international level. Teach. Teach. Educ. 2008, 24, 2027-2037.

53. Edwards, A.; Protherhoe, L. Learning to see in classrooms: What are student teachers learning about teaching and learning while learning to teach in schools? Br. Educ. Res. J. 2003, 29, 227-242.

54. Darling-Hammond, L. Powerful Teacher Education: Lessons from Exemplary Programs; John Wiley \& Sons: Hoboken, NJ, USA, 2012.

55. Morris, P.; Williamson, J. Teacher Education in the Asia-Pacific Region: A Comparative Study; Routledge: New York, NY, USA, 2013.

56. Gundem, B.B. Understanding European Didactics; Routledge International Companion to Education: New York, NY, USA, 2000; pp. 235-262.

57. Lin, H.L.; Gorrell, J. Exploratory analysis of pre-service teacher efficacy in Taiwan. Teach. Teach. Educ. 2001, 17, 623-635.

58. Runhaar, P.; Konerman, J.; Sanders, K. Teachers' organizational citizenship behaviour: Considering the roles of their work engagement, autonomy and leader-member exchange. Teach. Teach. Educ. 2012, 30, 99-108.

59. Vallerand, R.J.; Pelletier, L.G.; Blais, M.R.; Briere, N.M.; Senecal, C.; Vallieres, E.F. The academic motivation scale: A measure of intrinsic, extrinsic, and amotivation in education. Educ. Psychol. Meas. 1992, 52, 1003-1017.

60. Archer, J. Achievement goals as a measure of motivation in university students. Contemp. Educ. Psychol. 1994, 19, 430-446.

61. Grey, J.; Sime, N. Findings from the national survey of teachers in England and Wales. In The Elton Report: Discipline in Schools; HMSO: London, UK, 1989.

62. Kline, R.B. Principle and Practice of Structural Equation Modeling; The Guildford Press: New York, NY, USA, 2005.

63. Følgegruppen. Lererutdanninger i Endring. Indre utvikling-Ytre Kontekstuelle og Strukturelle Hinder [Teacher education in change: Internal development-External contextual and structural constraints]; University of Stavanger/Følgegruppen for lærerutdanningsreformen: Stavanger, Norway, 2014. (In Norwegian).

64. Roksvaag, K.; Texmon, I. Arbeidsmarkedet for Lerere og Førskolelcrere Fram mot år 2035 [The work market for teachers and kindergarten teachers towards 2035]; Report no. 18; Statistics Norway: Oslo, Norway, 2012. 
65. Kjærnsli, M.; Olsen, R.V. Fortsatt en vei å gå. Norske Elevers Kompetanse i Matematikk, Naturfag og Lesing i PISA 2012. [Still a way to Go. Norwegian Pupils' Competencies in Mathematics, Science and Reading in PISA 2012]; Universitetsforlaget: Oslo, Norway, 2013. (In Norwegian)

66. Zeichner, K.; Bier, M. The turn toward practice and clinical experiences in US teacher education. Beitr. Zur Lehr. 2013, 30, 153-170.

(C) 2015 by the authors; licensee MDPI, Basel, Switzerland. This article is an open access article distributed under the terms and conditions of the Creative Commons Attribution license (http://creativecommons.org/licenses/by/4.0/). 